https://doi.org/10.52449/1857-4114.2021.37-1.12

CZU: 373.03:796.012+37.015

\title{
ADOLESCENCE PERSONALITY TRAINING THROUGH EXTRACURRICULAR MOTOR ACTIVITIES
}

\author{
Pozînărea Remus ${ }^{1}$, ORCID: 0000-0002-1792-3042 \\ Calugher Viorica ${ }^{2}$, ORCID: 0000-0003-0405-5917 \\ ${ }^{1}$ National Colege "V. Alecsandri", Bacau, Romania \\ ${ }^{2}$ State University of Physical Education and Sport, Chisinau, Republic of Moldova
}

\begin{abstract}
The issue of education acquires new connotations in contemporary society, given by unprecedented changes in all areas of social life. The emphasis shifts from the informative to the formative. Education transcends the boundaries of the school curriculum and tends towards lifelong learning. A unitary curriculum can no longer respond to human diversity alone, and the goal of lifelong learning tends to become an indisputable reality. Thus, without denying the importance of curricular education, it becomes increasingly obvious that extracurricular education, i.e. that achieved beyond the educational process, has its role and place well established in shaping the personality of young people. Sociological research, conducted in four colleges in Bacau, Romania (National College "Vasile Alecsandri", Technical College of Communications "Nicolae Vasilescu-Karpen", National College "Ferdinand" and National College "Gheorghe Vrănceanu") during September - October 2020 on a sample of 210 people (130 high school students, 80 parents), aimed to identify the opinions of students and their parents on the main aspects of extracurricular activity: the degree of involvement of students in extracurricular activities; the level of partnership relationship of the school with the family in carrying out extracurricular activities; types of extracurricular activities; the ways of organizing them; the level of motivation to participate in extracurricular activities; the advantages and disadvantages of extracurricular motor activities and the opportunities they offer.
\end{abstract}

Keywords: extracurricular activity, formal and informal education.

Introduction. Education transcends the boundaries of the school curriculum and tends towards lifelong learning. A unitary curriculum can no longer respond alone to human diversity, and the desire for lifelong learning tends to become an indisputable reality. The school, no matter how well organized, no matter how rich the curricular content it communicates to the student, cannot satisfy the thirst for investigation and creative courage - specific features of children.

They need actions to expand their spiritual world, to fulfill their thirst for knowledge, to create states of deep emotion, discovering, appreciating, and forming their own beliefs, attitudes, behaviors [4]. Extracurricular activity as an educational phenomenon has a number of peculiarities and is subject to specific pedagogical requirements, which teachers must know and take into account. It allows the efficient and pleasant use of students' free time, the development of associative life, the development of abilities to work in groups and to cooperate in solving complex tasks, the development of will and the formation of positive character traits [3].

The main concern of physical education is to capitalize on the child's free time, time that acquires a special significance for the generation in training. The content of the 
child's free time, his "occupation" with useful activities, including sports activities, is at the center of the concerns of sociologists, but especially of specialists in education, educators, pedagogues, psychologists: Angelescu C., 1999 [1]; Bota A., 2006 [2]; Cretu T., 2009 [5]; Cucoş C., 2006 [6]; Dragomir P., Scarlat E., 2004 [7]; Stănescu M., Bejan R., Vasiliu A., 2009 [8].

The purpose of the research is to identify the opinions of students and their parents on the main aspects of extracurricular activity: the degree of involvement of students in extracurricular activities; the level of partnership relationship of the school with the family in carrying out extracurricular activities; the types of extracurricular activities required by students; the ways of organizing them; the level of motivation to participate in extracurricular activities; the advantages and disadvantages of extracurricular deadly activities and the opportunities they offer.

\section{Research results and their interpretation}

To achieve the purpose of the research, two questionnaires were applied: for middle school students and for their parents, and the most relevant results obtained from their application will be presented below.

The interpretation of the data in the questionnaire revealed the following opinions of the students' parents:

When asked about the benefits of educational activity organized outside the school curriculum of students, of the 80 subjects surveyed, the overwhelming majority $92 \%$ appreciated extracurricular activity as beneficial for students (Figure 1).
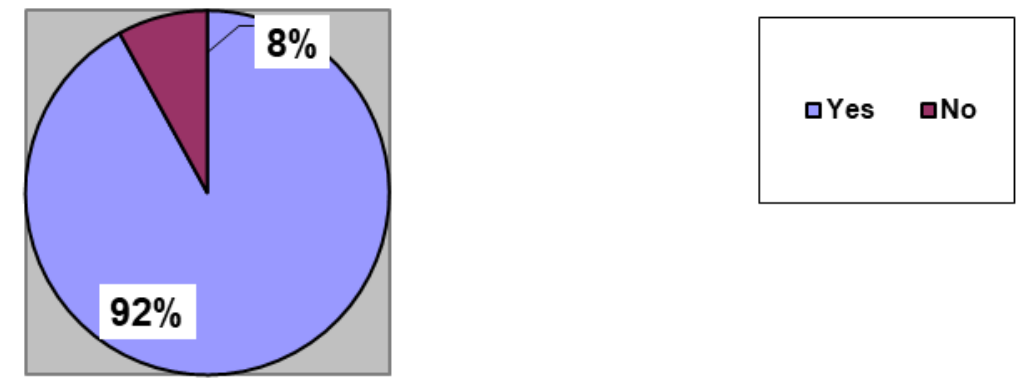

\section{Fig. 1. Graphic reflection of students 'parents' responses to the benefits of extracurricular activities for students}

In this context, we mention that the positive attitude of students' parents, towards extracurricular activities is a favorable condition in the school-parent partnership in order to organize children's free time.

Regarding the advantages and disadvantages of extracurricular activities, the answers of the students' parents were distributed as follows:

- Advantages of extracurricular activities: developing children's personality and emotional intelligence - $32 \%$, socializing informally - $27 \%$, learning really useful things - $11 \%$, increasing confidence - $8 \%$, identifying and developing children's talents and skills $8 \%$, does not leave time for activities and malicious entourage - $7 \%$, others;

- Disadvantages: $57 \%$ of the respondent parents stated that there are no disadvantages of extracurricular activities; involvement in too many activities leads to overwork of the child - $22 \%$, involvement in activities that do not excite the child (achieving their own dreams or fashion trends) $-9 \%$, the purpose of 
participating in these activities is the desire of parents to be proud of the child's performance $-5 \%$, others.

On the question: To what extent are you motivated to enroll your child in extracurricular activities? the parents' responses were as follows (Figure 2):
a) to a large extent $-71 \%$
b) to a sufficient extent $-21 \%$
c) to a small extent $-8 \%$.

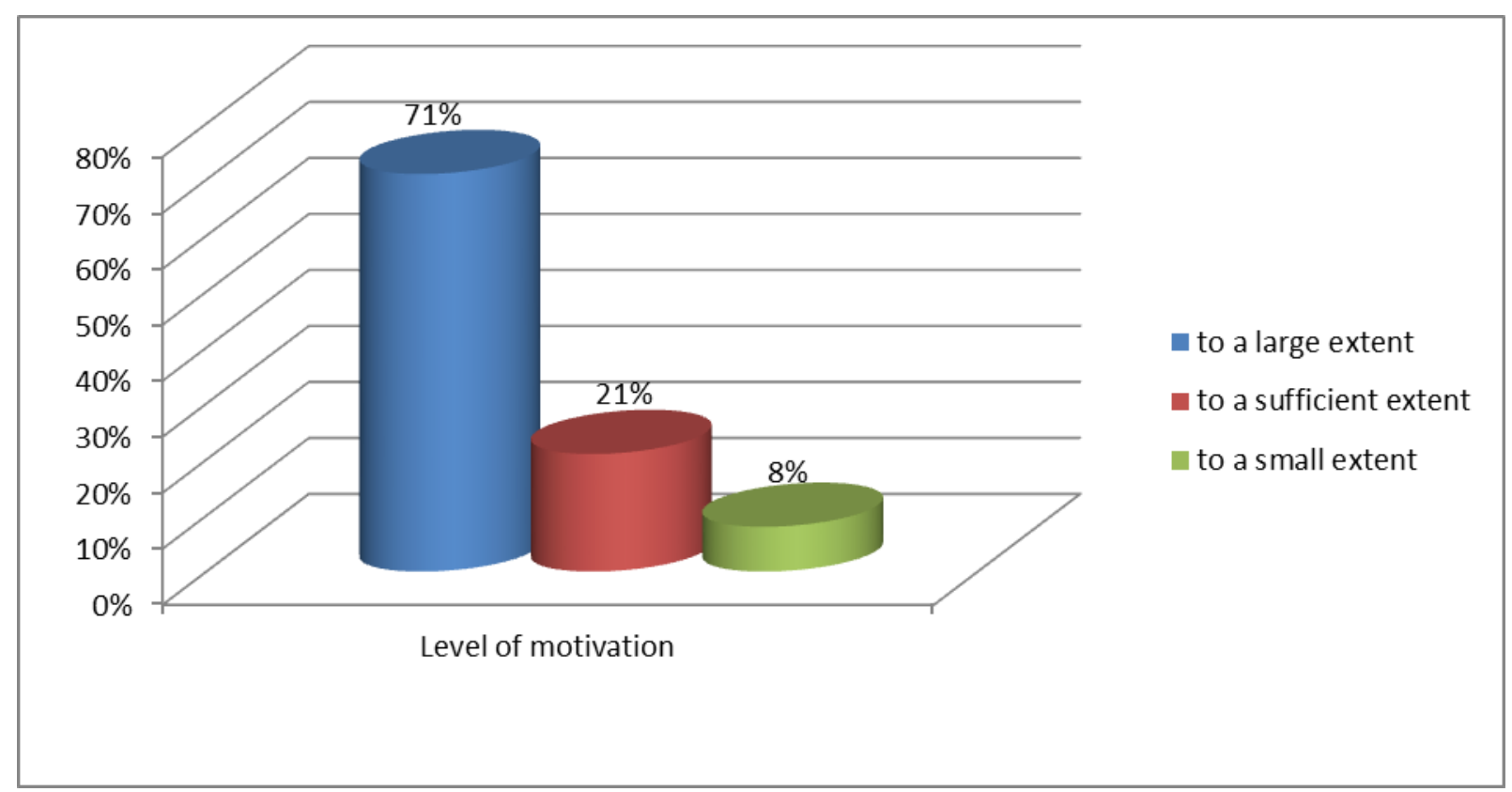

Fig. 2. Graphic reflection of the answers regarding the motivation of parents to enroll their children in extracurricular activities

To the question: What is the level of partnership of the school with the family in the development of extracurricular activities?, $65 \%$ of the respondent parents consider that it is a high level, $30 \%$ - medium level, and $5 \%$ of the parents consider it to be at a lower level (Figure 3).

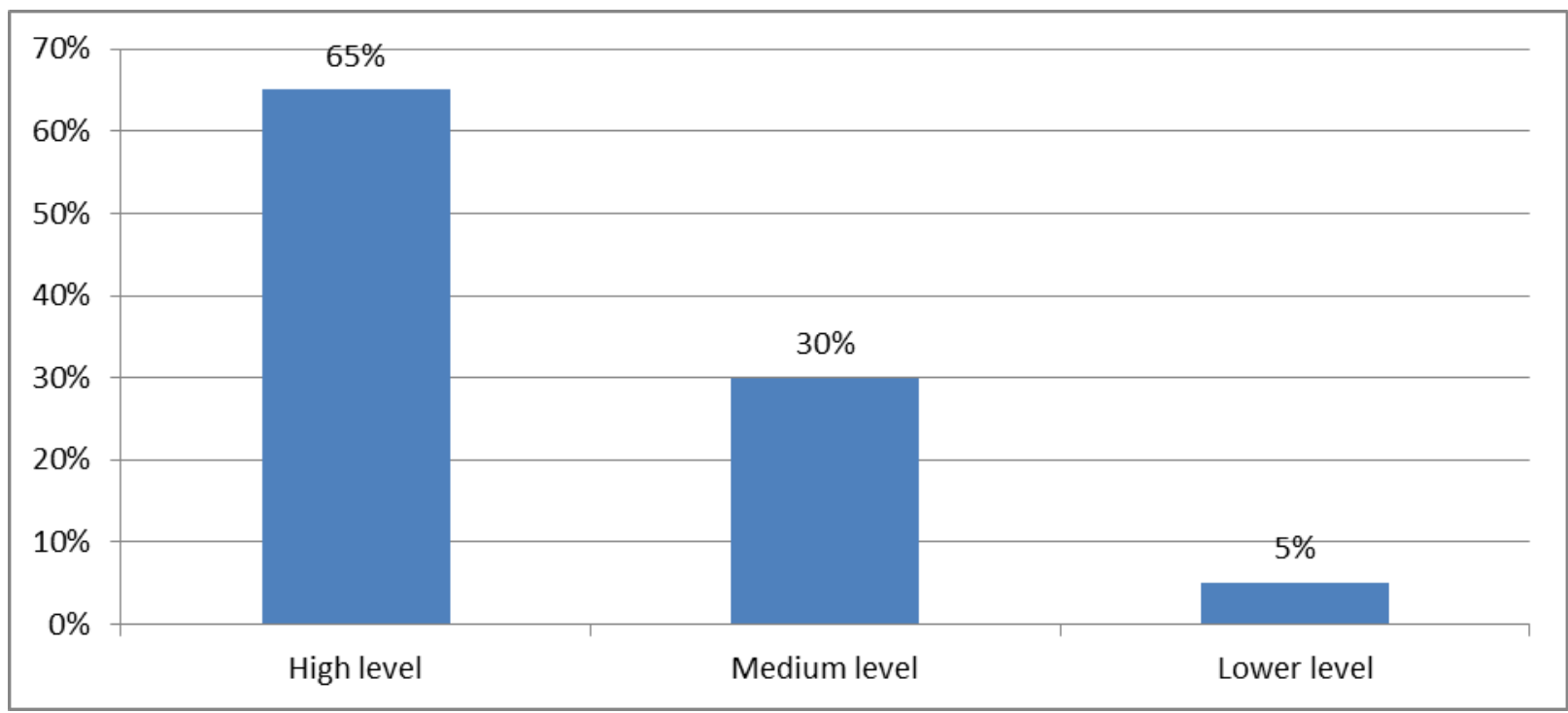

Fig. 3. Graphic reflection of the parents' answers regarding the level of partnership relationship of the school with the family in the development of extracurricular activities 
The answers demonstrate the active involvement of parents in the extracurricular life of children and, through this, the participation in the extracurricular life of the child, in this way, ensuring the monitoring of the child's activity outside school.

Regarding the extracurricular activities (or, the field of activities) that the parents consider to meet the needs of the child, it was found that most parents indicated the field of physical education and sports - 62\%, recreation and active leisure - $12 \%$, education for health $-8 \%$, arts (music, painting, sculpture, theater) $-7 \%$, others $-5 \%$ (Figure 4 ).

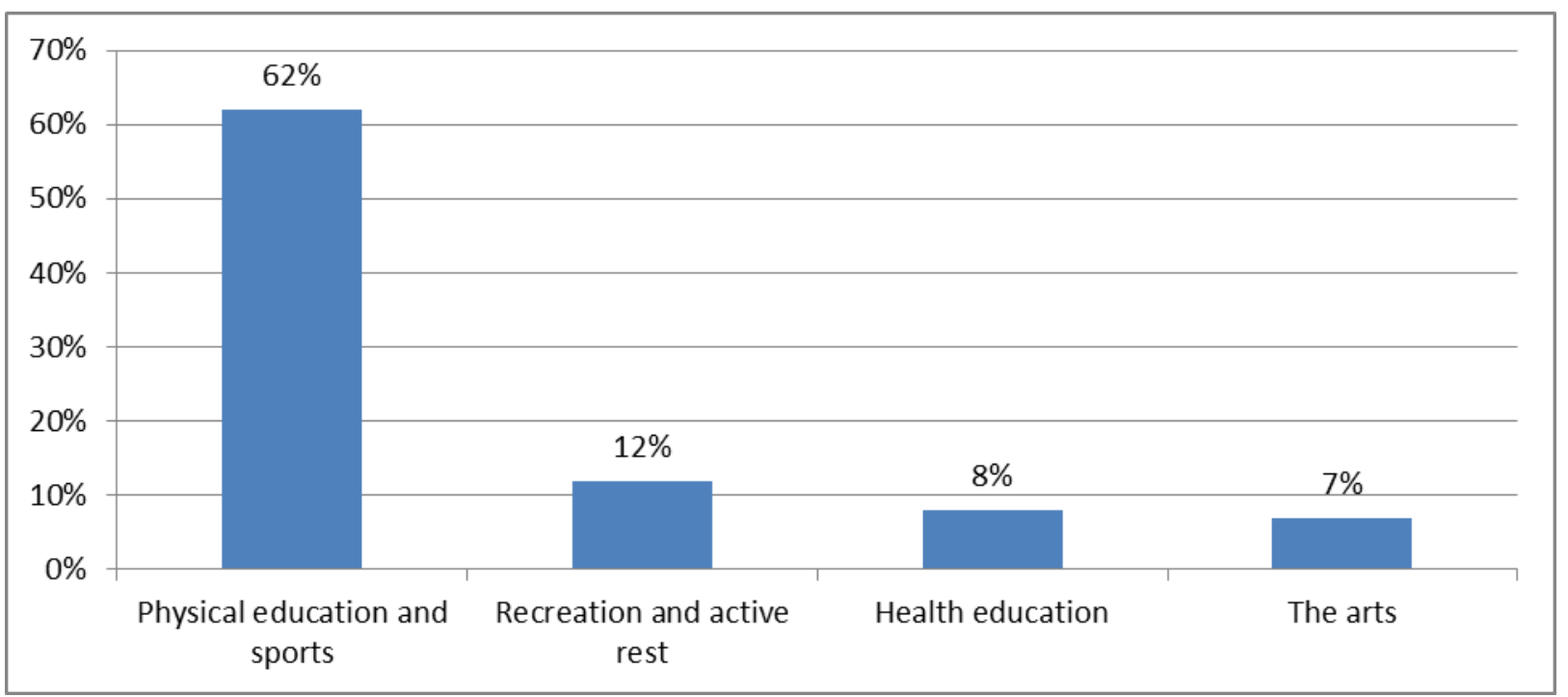

Fig. 4. Graphic reflection of parents' responses to the areas of extracurricular activity needed by children

Starting from the answers obtained from the students` parents, we can conclude that they highly appreciate the benefits of extracurricular activities, are interested in this topic and are actively involved in the partnership with the school in order to organize children's free time. This indicates the need to involve students ' parents in school and extracurricular life, which is a source of information and motivation for parents to identify children's options on areas of activity, which are then necessary for children's career guidance.
The analysis of the answers obtained following the application of the questionnaire of the students of the gymnasium classes allowed to obtain the following results:

To the question asked to the students: Is the educational activity organized outside the school program welcome?, most answered in the affirmative $-82 \%$, denied the benefit of these activities $11 \%$, and $7 \%$ of the students could not answer this question (Figure 5), which reflects the positive attitude of students towards extracurricular activities and raises awareness of their role in developing their own personality. 


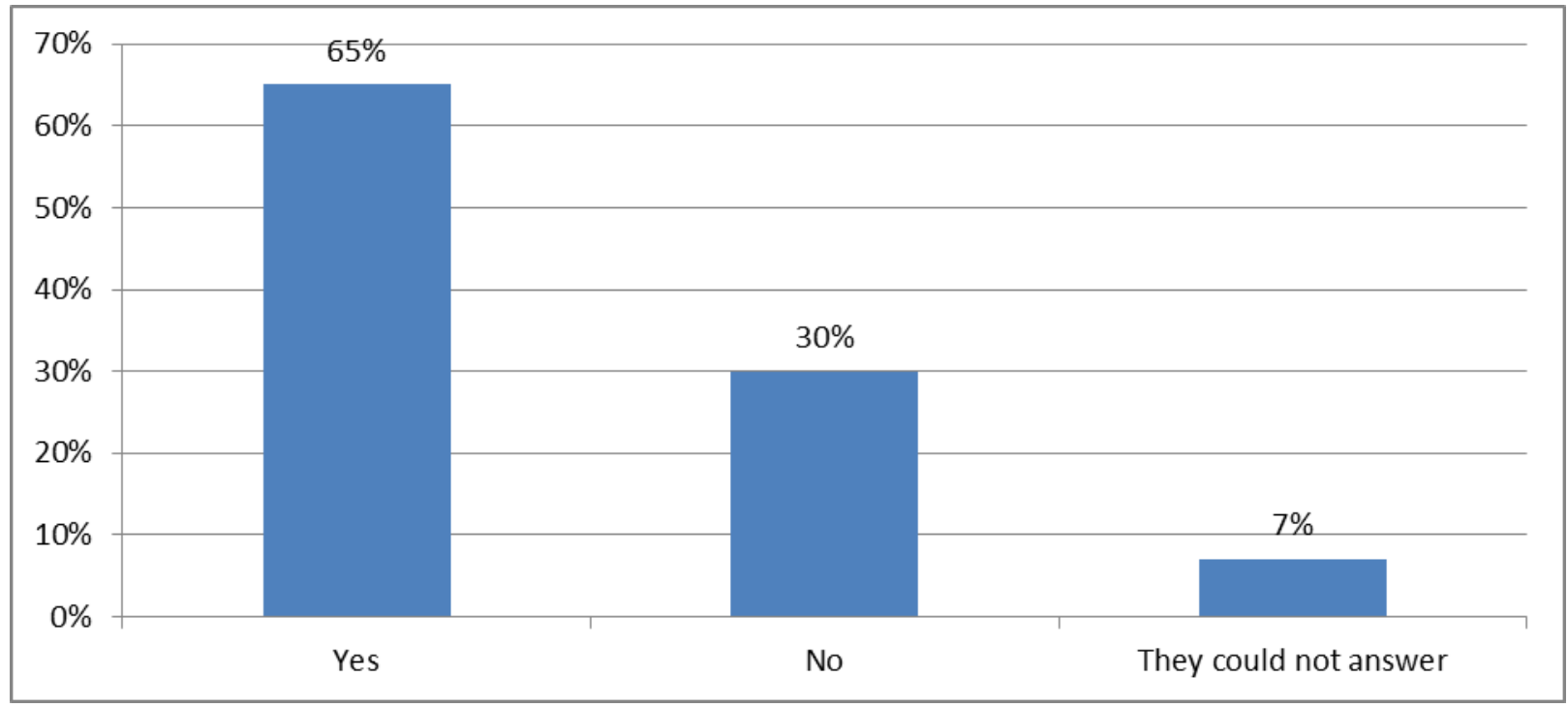

Fig. 5. Graphic reflection of students' responses to the benefits of extracurricular activities

The answers received to the question on the level of motivation of students to participate in extracurricular activities, indicating the source of motivation, show that $74 \%$ of students want to participate in these activities, being motivated by parents and teachers in choosing the field of extracurricular activity, about $18 \%$ are sufficiently motivated, being influenced by family members and friends, while $8 \%$ of responding students said they are less motivated and less discuss this topic with others. From the answers obtained we can see that school and family are the most important factors in terms of forming the motivation to participate in extracurricular activities, as well as those that can guide the child in the field closest to the child's needs and vocation (Figure 6).

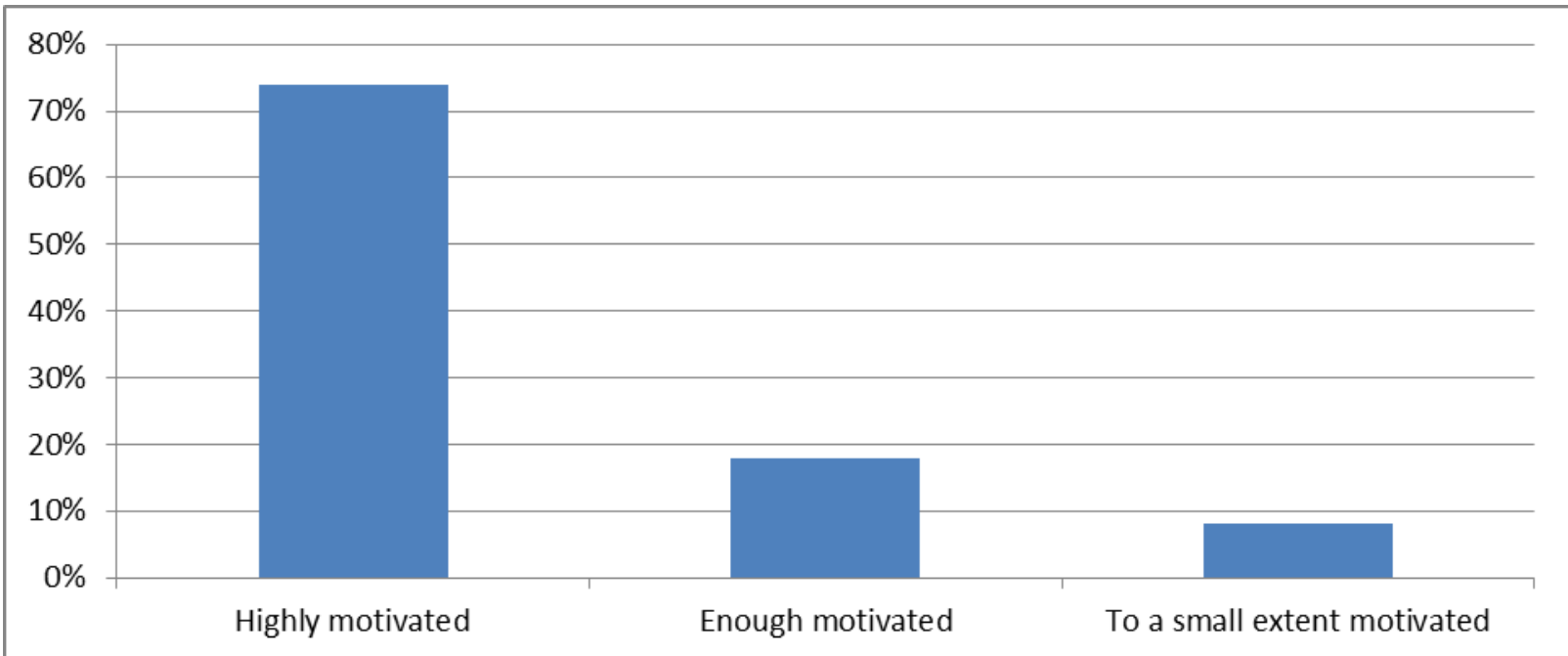

Fig. 6. Graphic reflection of students' responses to the level of motivation to participate in extracurricular activities

Asked to name the preferences for extracurricular areas / activities that would meet their needs and interests, the surveyed students opted for: sports activities - 48\%, 
artistic activities (theater, painting, music, dance) $-32 \%$, recreational activities, related to tourism and leisure $-12 \%$ and $8 \%$ for others.

From the answers obtained we can see the desire of children to participate in activities insufficiently developed in the school curriculum. At the same time, the results reflect the children's desire to participate in group activities, in which they can socialize with those who have the same preferences.

Asked if they are part of an extracurricular circle or participate in extracurricular activities, $55 \%$ said they participate in one way or another in extracurricular activities, and $45 \%$ of surveyed students said no. This percentage is not their real attraction to an extracurricular activity, the reasons can be various: the school / community does not offer extracurricular activities, low motivation or lack of it from the school, teachers, family and society in general, to which is added the insufficiency of the free time available to the students (especially from the gymnasium terminal classes).
Conclusion. The value of non-formal education consists in the multi-, inter- and transdisciplinary approach of some fields of great interest for the student, the extracurricular fortification of the variable component of general education, the contribution to the transfer of knowledge and skills accumulated by children in primary school and to the development of useful skills for the student, stimulating the interest and cognitive motivation of learners for training and personal development. The questionnaire addressed to students and their parents helped us to know the interests and needs of the respondents, the level of involvement in extracurricular activities and the perspective of developing this type of education. The results obtained will be the basis for further research on the development of extracurricular motor activities programs, whose main objective is the harmonious development of students' personality and their effective integration into the social environment.

\section{References:}

1. Angelescu C. (1999). Timpul liber. Bucureşti: Economică, p. 46-61.

2. Bota A. (2006). Exerciţii fizice pentru viaţă activă, activităţi motrice de timp liber. București: Cartea Universitară, p. 16-70.

3. Cebanu L. (2013). Aspecte metodologice ale activităţilor extraşcolare în învăţământul preuniversitar. În: Materialele Conferinţei știinţifice internaţionale, 18-19 octombrie, 2013, Chişinău, p. 757-761.

4. Cebanu L. (2015). Managementul activităților extrașcolare. Ghid metodologic. Chișinău: Institutul de Ştiinţe ale Educaţiei. 84 p.

5. Creţu T. (2009). Psihologia vârstelor. Ed. a III-a. Iaşi: Polirom, p.11-57, 237-312.

6. Cucoş C. (2006). Pedagogie. Ed. II-a revăzută şi adăugită. Iaşi: Polirom, p. 45-59, 108$110,181-358$.

7. Dragomir P., Scarlat E. (2004). Educaţia fizică şcolară. Bucureşti: Didactică şi Pedagogică. $211 \mathrm{p}$.

8. Stănescu M., Bejan R., Vasiliu A. (2009). Locul educaţiei fizice în bugetul de timp liber al elevilor din ciclul gimnazial. În: Forumul Științific national Universitar. Ediția I. 11-12 decembrie 2009, p. 14-17. 